TP Periodica Polytechnica Architecture

46(2), pp. 88-91, 2015

DOI: $10.3311 /$ PPar. 8245

Creative Commons Attribution (i)

RESEARCH ARTICLE

\section{Italian-Hungarian Relationships over 100 Years of Monument Preservation (1849-1949)}

\author{
Tamás Mezős ${ }^{1 *}$
}

Received 14 May 2015

\begin{abstract}
The beginnings of independent Hungarian monument preservation go back to the first half of the 19th century. The undertaking to form a legal body for the registration and protection of monuments began in the 1840s, with the National Monument Committee finally established in 1881. The paper analyses the most important Hungarian restoration works in the context of Italian monument restoration theories and practices of the investigated timespan; it also highlights the determining role of the Hungarian Academy in Rome through its patronage programmes for architects.
\end{abstract}

\section{Keywords}

monument preservation, Italian-Hungarian Architectural Realtionships, Italian monument restoration theories and practices

\section{Precedents}

The beginnings of independent Hungarian monument preservation go back to the first half of the 19th century. Similarly to other European countries, Hungary also established societies that targeted the protection of the nation's history, memorable events, historical monuments and places, and as such, the preservation of traditions. From the 1840s, the Company of Hungarian Doctors and Natural Scientists strived to create the legal framework necessary for the registration and protection of relevant architectural landmarks. By 1847, the organisation already had its independent Archaeological Department. Its members mandated representatives from their itinerary Congress at Sopron to attend the Bratislava Parliament in order "to instruct their deputies to create laws that would enable the National Museum to officially acquire all the old remnants and treasures that would appear from the depths of the earth after having paid their due counter value." Although the 1848-49 freedom fight and the ensuing two decades impeded the establishment of Hungarian monument preservation and its legal background, the struggle ultimately paid off, when Minister for Cultural Affairs Tivadar Pauler created the Temporary Committee of Hungarian Monuments in 1872, within the framework of his sphere of activities. The task of the body was to create an inventory of all the historical buildings, as well as to begin the conservation and restoration of the monuments. No less importantly, the Minister asked the Committee to draft the text of the Monument Act. By promulgating Act XXXIX of 1881, the Temporary Committee ceased, and the National Monument Committee came about. To ensure the continuity of the work carried out by the two bodies, the new organisation carried on the registration and listing of the monuments. It ensured their upkeep and restoration, and just as significantly, popularised their existence.

The story of the restoration of the Zsámbék Church, dating from the 13th century but in a ruined state since the mid16 th century, is exemplary. The alarming state of the building required rapid intervention. A professor at the Technical University, István Möller, used bricks for the reinforcement works, similarly to the restoration of the Colosseum carried out in the early 1800 s (Valadier and Stern). The continuity of the structure 
had to be ensured from the start. A huge flying buttress was built on the north side of the eastern ridge, in front of the apse of the side-aisle. The brick addition was finished off with a wall crown made of stone; the centre of the ridge wall was protected from the damaging effect of penetrating damp with a similar crown. He had the stone finish of the remaining southern hatch wall demolished and replaced with bricks. The finish was once more carried out with stone elements. The most important interventions were carried out by the addition of the western facade portal. The portal elements on the right side were made of bricks, and followed the form of the wall structure. Möller had the fragments, which were in a poor state or already destroyed, recarved and replaced with stone or artificial stone, especially if the original form was clearly identifiable.

Möller's activity ensured the preservation of a similarly important monument in Pécs, namely the restoration and presentation of the early Christian necropolis in the vicinity of the Cathedral.

The principles of the Prima Carta del Restauro charter as applied to the key restorations of the interwar period.

Camillo Boito, the professor of the Milanese Brera Academy, defined his views on monument preservation at the III Rome Congress of Architects and Engineers in 1883. The six clauses of Italian monument preservation are usually referred to as the Prima Carta del Restauro. A conference was held in 1912 to honour him, to which Gustavo Giovannoni produced a newly compiled volume. The 'La tutela delle Opere d'Arte in Italia' recognises the importance of all aspects of Boito's work. He identified himself with the previously much-disputed principle, according to which, of Viollet-le-Duc's views on monument preservation principles, only the theses regarding research and documentation should be applied; otherwise, new approaches are to be found. In addition to the importance of established historical knowledge, Giovannoni also treated the significance of the technical aspects of monument preservation accordingly. Italy had its great period of monument preservation in the 20s and 30s; large classical restorations were being carried out during this period throughout the country. They included the Forum region in Pompeii, the Temple of Jupiter, a complete set of apartment houses, such as the house of the Vettius family, the Menandros house, the Casa del Fauno, the peristyle of the Casa d'Argo in Herculaneum and the Cave of the Sibyl. The list of locations could also include Sabrath, Leptis Magna and Pula, where Italian architects carried out their activity.

Giovannoni was one of the initial authors of the first Italian law on monument preservation (Carta del restauro italiana 1931). He also undertook an important role later when drafting the document that became known as the Athens Charter. The need for restoration to be carried out based only on objective and scientific aspects is very clearly defined in both texts, emphasising the historical and documentative aspects of the monument.
With the cultural boom following the First World War, in Hungary, it was artists, together with art historians and architects who were able study the great periods of Italian culture at the Roman Hungarian Academy, established within the framework of the patronage programmes organised by Minister of Culture Kunó Klebelsberg. The Academy had applied a very conscious theoretical and ideological set of values ever since its creation. Tibor Gerevich's view, which defined the theoretical character of the Roman school and rebuffed extremes, can be linked to the values that recreated the Grand Roman style and related to the Italian viewpoint of the $20 \mathrm{~s}$ and $30 \mathrm{~s}$. The change became logical and natural when Gerevich took over as President of the National Monument Committee after returning from Rome in January 1934. The five years' experience in Rome also helped the transformation of the body. Two excellent experts aided his work, István Genthon - who became one of the most determining personalities of national monument inventorying, as a former Roman scholar and art historian - and architect Kálmán Lux, Möller’s disciple.

Based on this, it is clear that the most important monument restorations carried out in the interwar period could only be executed based on principles generally accepted in Europe, as the leaders of the National Monument Committee were related to Italy and the Italian practice of monument preservation in their activities or professional background.

\section{Presenting the Royal Seat of Visegrád and Esztergom}

When preparing for the 900th anniversary of the death of Hungary's King Saint Stephen, the National Monument Committee decided to restore and present the medieval royal seats as monuments. It was Imre Henszlmann who began researching the Visegrád Citadel at the end of the 19th century. Lightning struck and destroyed the presentation Frigyes Schulek - the Purist restorer of Matthias Church in Buda - made of the Solomon Tower; the task of its reconstruction fell to János Schulek, architect of the National Monument Committee. The palace, initially built by Charles I of the House of Anjou, was extended first by Sigismund at the turn of the 14th century, then by Matthias in the last quarter of the 15th century; becoming a significant creation of late medieval and early Renaissance Europe. Exploration started in 1932 under the supervision of János Schulek. It was suspended for a short period in 1944 due to the war, then continued after the war until Schulek's death (1948); the restoration of the monument was only completed at the beginning of the 50s. In 1934, excavations revealed the ornamental palace built by King Matthias. Fragments of the famous ornamental fountain - also known from literary works - appeared in the courtyard. Uncovered on the mountain side of the courtyard, parts of the bases of the cloister vault structure and several rib parts still remained as imprints on the walls. The theoretical reconstruction of the courtyard from Matthias's age 
was set out by Kálmán Lux, and by 1953, the restoration of one of the cloister sides was complete together with the reconstruction of the ornamental fountain in its original place, being the work of sculptor Ernő Szakál.

The walls, restored without a roof, were seriously damaged over time; János Sedlmayr restored the remaining parts in the 70s. When preparing for the millennial festivities, the cultural leadership decided to enlarge the royal seat. The last stage of restoration ended in the recent past, based on Gergely Buzás's research and according to Zoltán Deák's plans. The aim of the restoration was the reconstruction of the historical sites near the ornamental fountain based on the archaeological data and the available research results.

The restorations and partial reconstructions of the 50s were made of bricks to clearly differentiate the original stone parts of the palace from its additions. The latest presentations were made of stone while the profiled parts are artificial stone. Stone surfaces were whitewashed - maybe too precisely - in order to differentiate them. Esztergom was explored and restored between 1934 and 1938 under the leadership of Kálmán Lux. Following the circumspect archaeological exploration that carefully considered the fine details, and based on Boito's principles, the remaining parts of the royal palace were presented in a way that respected architectural periods. Only the most necessary of material changes were implemented, together with additions justified for authenticity and illustration. The explored palace of the Árpád age, and especially the castle chapel, is considered an important example of 15 th to $16^{\text {th }}$-century Hungarian architecture. The original fragments were preserved during the restoration. The reconstruction of the historical sites - if research provided a sufficient base - was carried out with bricks thinner than the medieval ones. Almost all the vault ribs of the royal chapel concealing magnificent details were revealed. Thus, the vaults can be perceived partly as an anastylosis and partly as reconstruction in terms of vault caps. Parts of the mural paintings remain; these were presented to the public after preservation. As the loadbearing capacity of the structural elements was doubtful, concealed reinforced concrete elements were also used during the restoration. Concrete and reinforced concrete was widely used in the monument preservation activities of the $30 \mathrm{~s}$, as it was easy to use and shape, and could be readily differentiated from the original. Even the Athens Charter, accepted in 1931, encouraged the use of concrete as one of the modern materials to be used in monument preservation. Unfortunately, decades had to pass before the harmful consequences of the chemical processes between concrete and the original stonewall were recognised; consequently, the use of concrete in monument preservation was discontinued from the 1980s.

When presenting the Royal Seat of Esztergom, it is important to mention the Bakócz-Chapel. Cardinal; Archbishop Tamás Bakócz commissioned Italian Renaissance builders to construct and annex a funeral chapel to the medieval St
Adalbert Cathedral in 1506. The little chapel, made of red marble, miraculously survived the destruction of the Turkish age.

The new, Classicist cathedral was started in the second half of the 18th century, a creation summarizing the best of the Renaissance masters.

The castle was enlarged with a new wing within the framework of the millennial restoration programme. However, the connection between the new segments and the original mass was not solved harmoniously.

\section{The Roman ruins of Szombathely and the Árpád- age ruins of Székesfehérvár}

Szombathely is an important scene of Hungarian monument preservation. János Szily, elected bishop in 1777, studied in Rome when Piranesi prepared his ancient engravings, and Winckelmann and Goethe lived in the city. Szily also discovered antiquity in Szombathely as the new Bishop's Palace was built on the former Roman settlement. He wished to explore scientifically the history of Savaria (Roman Szombathely), and Menyhért Hefele's building design for the palace already included a plan for the placement of the Roman carved stones. The Sala Terrena was built in a way that allowed the exhibition of the Roman stone ruins appearing from the construction site. István Schoenviesner wrote his work on the ancient predecessor of Szombathely relying on ancient Roman authors. Schoenviesner, the first in Hungary to erect a protective building over the remains of the Thermae Maiores unearthed on the grounds of the Aquincum Castrum, had the misfortune to be mandated to write his book only after the foundations of the Bishop's Palace had already been laid. Although he had the volume completed before the construction of the palace ended, he was unable to see the remains of Savaria revealed during the excavation. The Roman ruins revealed in the garden of the Bishop's Palace remained untouched during the 19th and 20th centuries. It was István Járdányi Paulovits who carried on the systematic excavations between 1937 and 1941. In order to protect the mosaics of the building he had found and identified as the imperial assembly hall, Kálmán Lux designed a protective building with an unplastered brick facade and a shallow roof evoking Tuscan architecture. It blends harmoniously into the view of the complex, presenting the preserved ruins in a park-like environment. The borders of the original space do not coincide with the area covered by the protective building, which thus could not evoke the atmosphere of a Roman interior.

The remains of the Székesfehérvár basilica from Saint Stephen's age were first uncovered in the second half of the 19th century, when Imre Henszlmann cleared the ground plan of the church discovered in the garden of the Bishop's Palace. The church was unearthed once more between 1936 and 1938, as a preparation for the festivities related to the 900th anniversary of the death of Hungary's first king. The predecessor of the ruin garden, visible today was created at that time (1937-39). 
The remains of the wall were not preserved; however, the church interior was restructured. The early medieval remains were only highlighted in 1972, to the detriment of the annex built by King Matthias. ${ }^{1}$ The current appearance is the result of work carried out in the $80 \mathrm{~s}$. The light structured cover of the aisle section behind the Western entrance was constructed in preparation for the millennial festivities. The southern tower was also slightly raised. The related programme designated one of the neighbouring houses to serve as storage for stonework finds. In the current urban structure, the whole layout of the basilica is not fully visible. The bridge-like pedestrian passage built over the southern side-aisle covers the southern wall of the basilica. The protective roof exerts pressure precisely on this wall section with the site of the wall and buttress indicated on the floor. The protective roof leans on the row of pillars separating the northern side aisle from the main aisle. ${ }^{2}$ At the end of the $1930 \mathrm{~s}$, storage for the unearthed valuable stone remains was built according to the plans of Kálmán Lux and Géza Lux, together with a mausoleum for Saint Stephen's sarcophagus. The new buildings integrated the former Episcopal garden into the city web as if it were a gate. The garden fence on the ruined side, along the east-west axis, was used to place less valuable stone materials under a protective roof with a half saddle. The arcade, with an unplastered brick façade and covered with a shallow roof, was placed behind the basilica apse. The best examples of medieval stoneware and stone remains uncovered during the excavations were displayed in a high-quality storage exhibit. The sarcophagus, known as Saint Stephen's resting place, found immediately next to the gate structure, is an elaborately carved stone chest, larger than the previous one. The interior of the small mausoleum is decorated with Vilmos Aba-Novák's fresco evoking emotions and representing the significant figures of Hungarian history.

\section{The historical nucleus of the new Óbuda city centre, the starting point of the Via Antiqua}

In Óbuda, at the crossroads of Nagyszombat and Lajos street, sat a group of single storey residential buildings on 16 plots covering an elliptical area known as Királyhegy (King's Mount). The Roman mural remains in their cellars were well known, but it was only in 1925 that the second amphitheatre of Aquincum was discovered here. The excavations, begun in 1935, quickly cleared the ground plan of the arena theatre, the largest of its kind in the provinces north of the Alps, with a capacity of 13,000 people. Its arena was also well suited for the organisation of naval battles (naumachia). The restoration of the Óbuda military

1 The ruins of the extended chancel of the medieval church built under King Mattias were removed (archaeologically excavated) in favour of showing the early medieval period.

2 Later, the city council and professional experts rejected the protective roof, and the investment was halted. The city council decided to tear down the protecting light structure that was in sharp contrast with the cityscape. amphitheatre became László Gerő's task, who as a scholar of the Collegium Hungaricum of Rome had personal knowledge of the restoration of the Forum Romanum. In accordance with Gerö's decision, walls in a good state were preserved. Where the original walls had already been removed, only a location inferred from the reconstruction of the base ditches and ground plan was possible, so Gerő planned an addition of didactical intent to these parts of the site. During the restoration of the amphitheatre's varied structure, an annular-vault substructure and a tribune placed on an earth mound were also revealed. The western quarter of the substructure was reconstructed to approximately half its original height, with the restoration works continuing during the war between 1940 and 1943 .

A tender for the restructuring of Óbuda was announced in 1937. Of the competing works submitted, Viktor Olgyay, also from the Roman school (having spent a year in the Palazzo Falconieri in 1936), and his twin brother designed Óbuda to link the two Aquincum amphitheatres with a wide boulevard. The existing narrow streets full of small single-storey houses were fated for demolition. Their idea was to have the northern end at the former Roman city gate of the civic town and place the Aquincum ruins there. The nearly three-kilometre axis would have ended at Flórián Square with a cross-axis between Bécsi Street and Árpád Bridge. The end of the road would have been the military amphitheatre, which would have closed off the route. Huge residential buildings constructed in the spirit of rationalist architecture would have lined the road up to Flórián square. The Olgyay brothers wished to provide space for the presentation of the Roman ruins on both sides of the road leading from the square to the ruin garden, as well as along Mozaik Street bordered by an industrial plant.

\section{Epilogue}

In the post-war years, following the mass restoration necessary due to the destruction left by the conflagration, Hungarian monument preservation continued in the spirit defined by Tibor Gerevich. Boito's principles defined the starting point of the most important task of the age, the restoration of Buda Castle, which took takes several decades. They also set the standard when preserving smaller churches, urban flats, castles and palaces for future generations.

\section{References}

Altmann, J., Biczó, P. et al. (1996) Medium Regni. Nap Kiadó. (in Hungarian) Ceschi, C. (1970) Teoria e storia del restauro. (Theory and History of Restoration.) Rome. (in Italian)

Dercsényi, D., Zolnay, L. (1956) Esztergom. Képzőművészeti Alap Kiadóvállalata. (in Hungarian)

Gerő, L. (1959) Építészeti Müemlékek. (Architectural Monuments.) Műszaki Könyvkiadó. (in Hungarian)

Preisich, G. (1969) Budapest városépitésének története. (History of Budapest Urban Architecture 1919-1969.) Müszaki Könyvkiadó. (in Hungarian)

Szücs, J. P. (1987) A római iskola. (The Roman School.) Corvina. (in Hungarian) 